\title{
Topical Potassium Dobesilate
}

National Cancer Institute

\section{Source}

National Cancer Institute. Topical Potassium Dobesilate. NCI Thesaurus. Code C151946.

A topical formulation composed of an inhibitor of fibroblast growth factor (FGF), with potential antineoplastic activity. Upon topical administration potassium dobesilate selectively binds to and blocks the activity of FGF, interferes with the binding of FGF to FGFR and prevents FGFR-mediated signaling. This inhibits angiog enesis and tumor cell proliferation, and induces cell death in FGFR-overexpressing tumor cells. FGF plays a key role in angiogenesis, tumor cell proliferation, survival and invasiveness, and is upregulated in many tumor cell types. 